\section{Aktywność obywatelska młodzieży z niepełnosprawnością intelektualną. Społeczno-kulturowe bariery inkluzji}

Ditta Baczała, Celina Kamecka-Antczak

TEKSTY DRUGIE 2020, NR 2, S. 124-139

DOI: 10.18318/td.2020.2.8/ ORCID: Ditta Baczała 0000-0oo2-2761-2897

Celina Kamecka-Antczak oooo-0o01-8476-9738

$\mathbf{K}^{\circ}$

onwencja ONZ o prawach osób niepełnosprawnych (ratyfikowana przez Polskę w 2012 r.) postawiła za cel popieranie, ochronę oraz zapewnienie pełnego i równego korzystania ze wszystkich praw człowieka i podstawowych wolności przez wszystkie osoby niepełnosprawne, a także popieranie poszanowania ich przyrodzonej godności'. Zawarte w konwencji standardy postępowania zobowiązały państwa strony do wprowadzenia w życie wielu przedsięwzięć natury legislacyjnej, organizacyjnej czy edukacyjnej mających na celu umożliwienie osobom z niepełnosprawnością realizację ich praw. Idea społecznej inkluzji, która przyświecała twórcom konwencji, zakłada pełnoprawne uczestnictwo osób z niepełnosprawnością w każdej grupie społecznej. Państwa strony, podpisując konwencję, przyjęły także społeczny model niepełnosprawności², uznając między innymi, że

1 DzU 2012, poz. 1169.

2 Społeczny model niepełnosprawności narodził się w latach 70. XX wieku dzięki amerykańskim i brytyjskim aktywistom z niepeł-
Ditta Baczała -

dr hab., profesor

nadzwyczajny,

kierowniczka Ka-

tedry Rewalidacji,

Resocjalizacji i Opieki

Długoterminowej

UMK w Toruniu. Inte-

resuje się rozwojem

społecznym osób

z niepełnosprawno-

ścią intelektualną.

Ostatnio opubli-

kowała (pozycja

współautorska): In-

tymność-Rozwój-Edu-

kacja (2019). Kontakt:

dittab@umk.pl

Celina Kamecka-

-Antczak - dokto-

rantka w Instytucie

Nauk Pedagogicznych

Wydział Filozofii

i Nauk o Ziemi UMK

wToruniu. Interesuje

się realizacją praw

obywatelskich przez

osoby z niepeł-

nosprawnością

intelektualną.

Prowadzi warsztaty

edukacji obywa-

telskiej w szkołach

specjalnych. Współ-

autorka innowacji

społecznej „Wyzwania

Życia". Kontakt: celka.

kamecka@gmail.com 
niepełnosprawność jest pojęciem ewoluującym i że [...] wynika z interakcji między osobami z dysfunkcjami a barierami wynikającymi z postaw ludzkich i środowiskowych, które utrudniają tym osobom pełny i skuteczny udział w życiu społeczeństwa, na zasadzie równości z innymi osobami. $^{3}$

Społeczny model niepełnosprawności interpretuje ten stan jako rezultat luki pomiędzy kondycją biologiczną i możliwościami jednostki a barierami oraz oczekiwaniami środowiska fizycznego i społecznego. Luka ta powoduje trudności we wzajemnym dopasowaniu się, współistnieniu jednostki i społeczeństwa ${ }^{4}$ oraz pociąga za sobą niemożność zdobywania i realizacji przez osoby z niepełnosprawnościami praw społecznych i obywatelskich.

Ograniczenia funkcjonowania osób z niepełnosprawnością mogą mieć różne znaczenie w zależności od kontekstu historycznego, porządku społecznego, panującego systemu politycznego i gospodarczego. Pionier badań nad niepełnosprawnością i orędownik jej wspólnotowego modelu Victor Finkelstein określił trzy rodzaje dominujących barier społeczno-kulturowych ${ }^{5}$ : niekorzystną sytuację materialną, bezsilność i powszechność poniżających stereotypów kulturowych ${ }^{6}$. Zadaniem reprezentantów socjalnego modelu niepełnosprawności jest ,wyznaczanie koniecznych celów nowej polityki wobec niepełnosprawności, przezwyciężającej upośledzające społeczeństwo"

nosprawnościami i wyraźnie zmierzał do zmiany społecznej w postrzeganiu i interpretowaniu stanu, jakim jest ludzka niepełna sprawność. Zob. V. Finkelstein A Personal Journey Into Disability Politics, https://www.independentliving.org/docs3/finkelsteino1a.pdf (8.11.2019); M. Oliver The politics of Disablement, MacMillan, London 1990; tegoż Understanding disability: from theory to practise, MacMillan, Basingstoke, Hampshire 1996; Fundamental Principles of Disability, UPIAS 1976. Por. też Back to the Community - Disability Equality, "Rights and Inclusion”, https:// historicengland.org.uk (8.11.2019).

DzU 2012, poz. 1169, preambuła.

4 Por. M. Wiliński Modelowe strategie pomocy osobom z ograniczeniami sprawności: medykalizacja- usprawnianie - włączanie w: Diagnoza potrzeb i modele pomocy dla osób z ograniczeniami sprawności, red. A.I. Brzezińska, K. Smoczyńska, R. Kaczan, Wydawnictwo Naukowe Scholar, Warszawa 2010.

5 Por. T. Overmars-Marx, B. Pepping, F. Thomése Living apart (or) together-neighbours'views and experiences on their relationships with neighbours with and without intellectual disabilities, ") Journal of Applied Research in Intellectual Disabilities" 2018, v. 31, no. 6, s. 1008-1020.

6 C. Barnes, G. Mercer Niepełnosprawność, tłum. P. Morawski, Sic!, Warszawa 2008, s. 52.

7 Tamże, s. 21. 
i przełamującej głęboko zakorzeniony w kulturze europejskiej stereotyp bezradności i zależności niepełnosprawnych.

Informatyzacja gospodarki, zastąpienie słowa mówionego pisanym, zmiany w technologii komunikacyjnej czy pojawienie się rozwiązań technicznych kompensujących posiadane uszkodzenia ${ }^{8}$ wpłynęły pozytywnie na integrację społeczną osób z niepełnosprawnością fizyczną lub sensoryczną. Niestety, grupą najszerzej marginalizowaną i wykluczaną pozostają nadal osoby z niepełnosprawnością intelektualną ${ }^{9}$, wobec których poniżające stereotypy kulturowe wzmacnia między innymi nieprofesjonalna działalność dobroczynna ${ }^{10}$.

Społeczny model niepełnosprawności pozwala na przejście od indywidualnej narracji usytuowanej w sferze prywatnej do języka obywatelstwa i związanych z nim praw. Stacy Simplican, wyrażając obawy dotyczące niepełnosprawności w modelu społecznym ${ }^{11}$, zauważa, że niepełnosprawność ma wymiar nie tylko estetyczny i egzystencjalny. Ma również wymiar polityczny. Obecność niepełnosprawności w społeczeństwie ujawnia głęboką rozbieżność między konceptualizacją uczestnictwa politycznego a sposobami, w jakie działają politycznie ludzie niepełnosprawni ${ }^{12}$. Niepełnosprawność, podobnie jak płeć, seksualność, wiek, etniczność czy klasa społeczna, zostaje uznana za czynnik opresyjny, który determinuje związek ludzi ze wspólnotą i państwem, w których żyją ${ }^{13}$.,Rzeczywiście ucisk był postrzegany jako wspól-

8 International Classification of Functioning, Disability and Health (ICF) - Międzynarodowa Klasyfikacja Funkcjonowania, Niepełnosprawności i Zdrowia (2001) zastąpiła terminy "uszkodzenie" (impairment) oraz "inwalidztwo" (handicap) terminem "niepełnosprawność" (disability). Por. M. Paluszkiewicz Prawne pojęcie niepełnosprawności, "Studia Prawno-Ekonomiczne” 2015, t. XCV, s. 77-98.

9 Wpływ ruchu rodziców osób z niepełnosprawnościq intelektualng na rozwój nauki i życie społeczne: raport z badań, Polskie Stowarzyszenie na rzecz Osób z Upośledzeniem Umysłowym, red. B.E. Abramowska, Polskie Stowarzyszenie na rzecz Osób z Upośledzeniem Umysłowym, Warszawa 2014.

Jest to rodzaj działalności charytatywnej, która utrwala wizerunek osoby z NI jako biorcy wszelkich świadczeń, w tym szczególnie finansowych. Ten rodzaj dobroczynności eliminuje np. rolę społeczną pracownika na otwartym rynku pracy, którą może realizować osoba z NI, będąca jednocześnie płatnikiem podatków.

Por. R. Lang The Development and Critique of the Social Model of Disability, University of East Anglia, Norwich 2001.

S. Simplican The Capacity Contract. Intellectual Disability and the Question of Citizenship, University of Minnesota Press, Minneapolis 2015. 
ny mianownik, który jednoczy wszystkie osoby niepełnosprawne, niezależnie od różnic w pochodzeniu społeczno-ekonomicznym i kulturowym"14.

Czy społeczna większość, która mieści się w dość wąsko zdefiniowanych kulturowo-zdrowotnych i ekonomicznych normach, traktuje osoby z niepełnosprawnością intelektualną jako pełnoprawnych obywateli? Większość w swoim kulturowo-społecznym stereotypie przewidziała dla „niewidzialnych obywateli” inne, systemowe role ${ }^{15}$. Osoby z tym rodzajem niepełnosprawności funkcjonują w społecznym szablonie wyłącznie jako jednostki wymagające opieki, rzadziej wsparcia. Uprzedzenia i stereotypy kształtowane przez brak wiedzy i doświadczenia ze wspólnej egzystencji z osobami z niepełnosprawnością intelektualną są wyjątkowo trudne do zmiany, a ich ewolucja jest czasochłonna ${ }^{16}$. Osoby z NI od momentu pojawienia się niepełnosprawności są obiektem wsparcia instytucjonalnego. Diagnoza niepełnosprawności intelektualnej jest wydawana w polskim systemie przez poradnię psychologiczno-pedagogiczną i stanowi początek systemowo przygotowanej społecznej izolacji poprzez kształcenie segregacyjne. Wczesne wspomaganie rozwoju dziecka z NI (rozwiązanie w małym stopniu zastępujące brak systemu wczesnej interwencji) odbywa się w kolejnej instytucji, na przykład w specjalnym ośrodku szkolno-wychowawczym. Naturalnie po nim dziecko z NI idzie do przedszkola, szkoły podstawowej i ponadpodstawowej (na ogół są to instytucje specjalne). Dorosłość osoby z NI jest zamknięta w systemie warsztatów terapii zajęciowych i domach pomocy społecznej. Polska jest jeszcze na etapie wstępnym pełnej realizacji zapotrzebowania na mieszkania treningowe i chronione ${ }^{17}$ dla dorosłych osób

14 R. Lang The Devolompment and Critique..., s. 20.

15 Przykładem roli systemowej, którą przypisało polskie prawo osobie z NI, jest przestarzała instytucja prawna w postaci ubezwłasnowolnienia. Skutkuje ona „ograniczeniem albo nawet odebraniem zdolności do czynności prawnych dużej populacji osób z niepełnosprawnością intelektualną lub psychospołeczną", M. Szeroczyńska Jeśli nie ubezwłasnowolnienie, to co? Prawne formy wsparcia osób z niepełnosprawnościq intelektualnq, Polskie Towarzystwo Prawa Antydyskryminacyjnego, Warszawa 2012, s. 7.

16 D. Baczała Niepełnosprawność intelektualna a kompetencje społeczne, Wydawnictwo Naukowe UMK, Toruń 2012, s. 55. Por. też A.E. Baumann Stigmatization, social distance and exclusion because of mental illness: The individual with mental illness as a "stranger ${ }^{\prime \prime}$, ,International Review of Psychiatry" 2007 no. 19, s. 131-135.

17 Mieszkania treningowe i chronione są to lokale, które uczą samodzielności i niezależności dorosłe osoby z NI na mocy Ustawy z dnia 12 marca 2004 r. o pomocy społecznej, DzU 2019, poz. 1507. 
z NI. Izolacja instytucjonalna osób z niepełnosprawnością intelektualną jest cechą nie tylko Polski, ale wszystkich krajów dawnego bloku wschodniego. Dodać należy, że w zróżnicowanej grupie społecznej osób z NI są też takie, dla których instytucja specjalna jest jedyną właściwą placówką do rehabilitacji, edukacji i terapii.

Jak zauważa Elżbieta Zakrzewska-Manterys, większość programów, grantów czy inicjatyw, szczególnie związanych ze społeczną inkluzją, jest adresowana do osób o wysokim potencjale intelektualnym ${ }^{18}$. Wykluczenie osób z niepełnosprawnością intelektualną z głównego nurtu życia społecznego implikuje brak możliwości zdobywania przez nich wiedzy, umiejętności i kompetencji, dzięki którym mogłyby umiejętnie korzystać z przyznanych im praw, pełnić role społeczne adekwatne do wieku i rozwijać własną społeczną odpowiedzialnośćn ${ }^{19}$.

Na Zachodzie Europy i USA, gdzie dyskusja nad emancypacją osób z niepełnosprawnością toczy się od lat 6o. XX wieku, systematycznie pojawiają się publikacje dotyczące obywatelstwa osób z niepełnosprawnościami ${ }^{20}$. W Polsce temat ten jest nieobecny, szczególnie w kontekście powiązania niepełnosprawności intelektualnej i praw obywatelskich. Bezpośrednia implementacja rozwiązań zachodnich jest skomplikowana z powodów trudnych do jednoznacznego określenia (np. komunizm w Polsce, polska tradycja powstań zakończonych klęską).

Artykuł przedstawia analizę aktywności obywatelskiej uczennic i uczniów z niepełnosprawnością intelektualną szkół przysposabiających do pracy. W projekcie badawczym wykorzystano gotowe narzędzie - Kwestionariusz Kompetencji Obywatelskich KAO Ryszarda Klamuta (2015) z zastosowaniem ${ }^{21}$ odpowiedniej formy graficznej do możliwości kognitywnych osób z niepełnosprawnością intelektualną. Badania przeprowadzono

E. Zakrzewska-Manterys Upośledzeni umysłowo. Poza granicami człowieczeństwa, Wydawnictwo UW, Warszawa 2010, s. 102-104.

9 Por. P. Kubicki, R. Bakalarczyk, M. Mackiewicz-Ziccard Protests of People with Disabilities as Examples of Fledgling Disability Activism in Poland, "The Canadian Journal of Disability Studies" 2005, vol 8, no. 5, https://cjds.uwaterloo.ca/index.php/cjds/article/view/569 (10.11.2019).

N. Altermark Citizenship Inclusion and Intellectual Disability: Biopolitics Post-Institutionalisation, Routledge, 2017; Civil Disabilities: Citizenship, Membership, and Belonging (Democracy, Citizenship, and Constitutionalism), eds. N.J. Hirschmann, B. Linker, University of Pennsylvania Press, Philadelphia 2015.

Dostosowanie graficzne jest rozwiązaniem własnym. 
w paradygmacie emancypacyjnym interpretowanym jako „wyzwolenie z opresji niepełnosprawności"22.

\section{Metodologia}

Do eksploracji wybrano narzędzie badawcze w postaci kwestionariusza, którego rozmiar i prosto sformułowane twierdzenia pozwoliły na zastosowanie w przypadku osób z niepełnosprawnością intelektualną. KAO został opracowany na podstawie definicji aktywności obywatelskiej również autorstwa Ryszarda Klamuta. Według autora aktywność obywatelska to

aktywność społeczna jednostek (obywateli), będąca wynikiem indywidualnych motywów lub oddolnych inicjatyw społecznych, nastawiona na realizację interesu społecznego (dobra wspólnego), podejmowana ze świadomością praw i zobowiązań wynikających z funkcjonowania systemu demokratycznego w warunkach spełnianych przez tenże system. ${ }^{23}$

Jest to klasyczne, arystotelesowskie ujęcie aktywności obywatelskiej. Nawiązuje do społecznej natury ludzkiej zoon politikon/animal sociale, która sprawia, że jestestwo człowieka może w pełni realizować się tylko we wspólnocie ${ }^{24}$. Definicja Klamuta wyraźnie podkreśla, że aktywność obywatelska jest pojęciem szerszym niż aktywność polityczna, która odnosi się tylko do perspektywy władzy. Aktywność obywatelska to całe spektrum możliwych działań na rzecz wspólnoty, obejmujące różne działania jednostki. Osią podziału rodzajów aktywności obywatelskiej w modelu Ryszarda Klamuta są dwa kryteria:

1. Obszar zaangażowania, który obejmuje działania jednostki nakierowane na poprawę jakości życia współobywateli (służba) lub na współtworzenie systemu władzy, czyli zaangażowanie w rządzenie (władza);

2. Stosunek jednostki do grupy, zgodnie z którym człowiek podejmuje aktywność indywidualnie lub jako członek określonej zbiorowości, której

22 D. Pogórska-Jachnik Pedagogika emancypacyjna a pedagogika specjalna - kluczowe kategorie w emancypacyjnym dyskursie niepełnosprawności, "Interdyscyplinarne Konteksty Pedagogiki Specjalnej" $2015^{\prime}$ nr 10, s. 7.

R. Klamut Aktywność obywatelska jako rodzaj aktywności społecznej - perspektywa psychologiczna, "Studia Socjologiczne” $2013 \mathrm{nr} 1 / 208$, s. 192. 
jest lub czuje się częścią. Wyróżnić tu możemy aktywność w perspektywie jednostki (niezależną od grupy) i społeczności (zależną od grupy).

Powyższe kryteria pozwalają na opracowanie „mapy zaangażowania” jednostki w realizację interesu społecznego. Każda jednostka może podejmować jedno albo jednocześnie wiele różnych działań należących do wyodrębnionych w modelu Klamuta czterech kategorii aktywności obywatelskiej, to znaczy:

1. Społecznikostwa - charakterystycznego dla aktywności podejmowanej przez jednostkę dla innych i ze względu na innych;

2. Partycypacji społecznej - czyli działań związanych z udziałem jednostki $\mathrm{w}$ zorganizowanych grupach społecznych, $\mathrm{w}$ tym $\mathrm{w}$ demokratycznych procedurach podejmowania decyzji;

3. Indywidualnej aktywności politycznej - czyli własnej aktywności podejmowanej w perspektywie władzy politycznej; do tej kategorii należy tworzenie własnych opinii i ocen dotyczących strony rządzącej;

4. Partycypacji politycznej - polegającej na aktywnym udziale w organizacjach sprawujących władzę lub do władzy aspirujących na różnych szczeblach: od samorządowego do państwowego ${ }^{25}$.

Właściwości psychometryczne narzędzia (pozwalające na ustandaryzowany i zobiektywizowany pomiar) Klamut przedstawił w artykule Kwestionariusz aktywności obywatelskiej (KAO) - narzędzie do badania różnych rodzajów aktywności obywatelskiej ${ }^{26}$. Forma graficzna kwestionariusza została dodatkowo dostosowana do procesów poznawczych osób z niepełnosprawnością intelektualną. Powiększono czcionkę oraz interlinię, by umożliwić badanym śledzenie kolejnych pytań. Pod każdym twierdzeniem zastosowano poziomą skalę kolorową, aby ułatwić zrozumienie systemu odpowiedzi według pięciostopniowej skali Likerta oraz samodzielne zakreślanie odpowiedzi:

- „zdecydowanie nie” - kolor intensywnie czerwony

- „nie” - kolor bladoczerwony

- „ani tak ani nie" - kolor żółty

- „tak" - kolor bladozielony

- „zdecydowanie tak" - kolor intensywnie zielony.

R. Klamut Aktywność obywatelska jako rodzaj aktywności społecznej..., s. 194. jów aktywności obywatelskiej, w: Psychologia Społeczna, red. M. Lewicka, t. 10 (32), Wydawnictwo Naukowe Scholar, Warszawa 2015, s. 68-83. 
Druga część badań została przeprowadzona na podstawie teorii barier społeczno-kulturowych Victora Finkelsteina. Wyodrębnił on trzy rodzaje dominujących barier ${ }^{27}$, z których wyprowadzono wskaźniki. Na ich podstawie opracowano ankietę. Składała się z trzech części: subiektywna ocena sytuacji bytowej, subiektywna ocena własnej bezsilności, postrzeganie siebie przez pryzmat stereotypów.

Badania właściwe zostały poprzedzone przez badania pilotażowe. Celem badań pilotażowych była weryfikacja możliwości zastosowania kwestionariusza KAO do grupy badanych z niepełnosprawnością intelektualną w stopniu umiarkowanym. Sprawdzono, czy zmieniona forma graficzna kwestionariusza jest dla badanych rzeczywiście wygodniejsza i czytelna, a także czy zrozumiałe są wszystkie wyrazy i sformułowania zawarte w kwestionariuszu KAO oraz ankiecie badającej subiektywną ocenę własnej sytuacji. W wyniku badań pilotażowych dokonano drobnych poprawek w treści pytań i odpowiedzi w kwestionariuszu $\mathrm{KAO}^{28}$.

Założono, że społeczno-kulturowe bariery inkluzji uniemożliwiają osobom z niepełnosprawnością intelektualną aktywność obywatelską i prowadzą do wykluczenia ich z głównego nurtu życia społecznego. Analiza korelacji między wynikami kwestionariusza KAO a wynikami ankiety subiektywnej oceny doświadczanych barier miała zweryfikować to założenie. Analiza zebranych danych pozwoliła także odpowiedzieć na pytania:

1. W jakiej kategorii aktywności obywatelskiej modelu Ryszarda Klamuta badani uczniowie uzyskują ogółem najwyższe wyniki, a w jakiej najniższe?

2. Która z analizowanych barier społecznych jest przez badanych uczniów doświadczana najczęściej, a która najrzadziej?

W badaniach wzięło udział 20 pełnoletnich uczennic i uczniów (z orzeczoną niepełnosprawnością intelektualną w stopniu umiarkowanym) szkół przysposabiających do pracy. Osoby badane zostały wylosowane i wyraziły zgodę na udział w badaniach.

C. Barnes, G. Mercer Niepełnosprawność, s. 52.

Np. twierdzenie 8: "samodzielnie pomagam potrzebującym, udzielając swojego czasu i pracy” (wykreślono „samodzielnie”); twierdzenie 11: „tworzę własną ocenę działań klasy politycznej w kraju” (zmieniono na "mam własną ocenę działań klasy politycznej w kraju”); twierdzenie 12: „podejmuję spontaniczną aktywność w działaniach organizowanych przez organizacje pozarządowe, kościół, domy kultury itp." (zmieniono na "chętnie i dobrowolnie angażuję się w działania organizacji pozarządowych, parafii, domu kultury, szkoły, itp."); twierdzenie nr 13: „organizacja polityczna jest miejscem mojego zaangażowania w działania na rzecz innych" (zmieniono na „miejscem mojego zaangażowania w działania na rzecz innych jest organizacja polityczna”). 
Badani uczniowie uzyskali ogółem najlepsze wyniki w kategorii „społecznikostwo”, najsłabsze zaś w kategorii „partycypacja polityczna”, która jest kategorią o najniższym odchyleniu standardowym (zróżnicowanie odpowiedzi jest bardzo małe). Rzeczywiście żaden uczeń objęty badaniem nie prowadził w tym czasie i wcześniej tego typu aktywności. Organizacja polityczna nie jest miejscem zaangażowania i aktywności tych uczniów. Na pytanie dotyczące ich zaangażowania w aktywność polityczną (dla wszystkich uczniów ta aktywność była synonimem partii politycznej) zwykle odpowiadali przecząco. Trzech uczniów udzieliło uzupełniającej odpowiedzi, w której wyraziło chęć należenia do partii politycznej, gdyby była ona kołem szkolnym.

W kategorii „indywidualna aktywność polityczna” badani rzadko wybierali środkowy wariant odpowiedzi (,ani tak, ani nie”), dzieląc się raczej na grupę osób aktywnych i zdecydowanie aktywnych oraz świadomie i zdecydowanie biernych. Uczniowie świadomie dokonywali wyboru wśród odpowiedzi najbardziej skrajnych: z zaangażowaniem interesowali się sprawami politycznymi lub celowo przyjmowali postawę bierną.

Dane zebrane za pomocą kwestionariusza do subiektywnej oceny doświadczanych barier pozwoliły na rozpoznanie, której z przeszkód w inkluzji, wymienionych w społecznym modelu niepełnosprawności, badani uczniowie doświadczają najsilniej, a której najsłabiej.

Doświadczanie społeczno-kulturowych barier inkluzji opisanych przez Victora Finkelsteina zbadano za pomocą ankiety składającej się z trzech pytań, które dotyczyły kolejno: subiektywnej oceny własnej sytuacji bytowej, subiektywnej oceny własnej bezsilności oraz postrzegania siebie przez pryzmat poniżających stereotypów (ankieta własna). Odpowiedzi na pytania zostały ujęte $\mathrm{w}$ ramy pięciostopniowej skali. Z zebranych odpowiedzi na każde z trzech pytań kwestionariusza wyznaczono odpowiedzi modalne, czyli najczęściej występujące. Odpowiedzi wskazywały na brak odczuwanych barier w zakresie objętym pytaniami. Z badań wynika, że uczniowie najrzadziej doświadczają bariery ekonomicznej. Najczęściej odczuwaną barierą są ograniczenia z powodu własnej niepełnosprawności.

Na uwagę zasługują odpowiedzi udzielone na pytanie dotyczące postrzegania siebie jako osoby wartościowej. Badani określali siebie jako najważniejszych, ważniejszych niż pozostali domownicy lub inne osoby w ich otoczeniu.

Obliczono współczynnik r-Spearmana, który umożliwia określenie zależności między doświadczaniem społeczno-kulturowych barier inkluzji a aktywnością obywatelską uczniów. Zgodnie z przyjętą hipotezą uczniowie 
silniej doświadczający społeczno-kulturowych barier inkluzji wykazują się niższym poziomem aktywności obywatelskiej.

Współczynnik r-Spearmana dla wszystkich wariantów przyjmuje wartość dodatnią, co świadczy o istnieniu zależności między wynikami uzyskanymi w kwestionariuszu KAO a poziomem odczuwanych barier ${ }^{29}$. Im mniej odczuwanych barier, tym wyższy wynik KAO. Siła korelacji dla większości badanych wariantów jest jednak słaba. Najsłabsza jest dla kategorii „społecznikostwo”. Wyjątek stanowi kategoria „indywidualna aktywność polityczna”, w przypadku której współczynnik wskazuje na istnienie bardzo silnej korelacji.

Z komentarzy uczniów wynika, że poziom ich aktywności obywatelskiej w kategoriach „,społecznikostwo" $i$, partycypacja społeczna” jest zdeterminowany przez ofertę szkolną: uczestnictwo w kołach zainteresowań, wspólne organizowanie spotkań społeczności szkolnej, udział uczniów w zbiórkach charytatywnych, inicjowany przez szkołę uczniowski wolontariat, udzielanie przez uczniów wsparcia seniorom. Niska zależność pomiędzy społecznikostwem a odczuwaniem barier społeczno-kulturowych świadczy o silnej roli szkoły jako środowiska, w którym odbywa się naturalny i celowy trening społeczny $^{30}$. Małe wewnętrzne zróżnicowanie średnich wyników uczniów dla tych kategorii wskazuje, że trening ma podobnie wysokie oddziaływanie na wszystkich badanych uczniów. Właściwie kreowane warunki zewnętrzne (w tym przypadku w szkole) pozwalają w dużej części przewartościować cechy osobowościowe i temperamentalne osób z niepełnosprawnością intelektualną, a tym samym wspomóc nabywanie przez nie kompetencji społecznych $^{31}$.

Wskazywane przez badanych odpowiedzi dla kategorii „indywidualna aktywność polityczna" i komentarze do nich pozwoliły podzielić uczniów na dwie grupy: osoby zainteresowane sprawami politycznymi i osoby nieinteresujące się nimi. W pytaniach kwestionariusza dotyczących tej kategorii uczniowie nie wybierali odpowiedzi środkowej (neutralnej). Wysokie zróżnicowanie wyników uzyskanych przez uczniów w kategoriach politycznej aktywności obywatelskiej nieinicjowanej w przestrzeni szkolnej wskazuje na rolę rodziny w przedmiotowej aktywności. W świetle teorii uwarunkowań

K. Rubacha Metodologia badań nad edukacją, Editions Spotkania, Warszawa 2008.

B. Matyjas Rodzina - szkoła - środowisko lokalne jako synergiczna przestrzeń socjalizacji, „Horyzonty wychowania" $2017 \mathrm{nr}$ 16/28, s. 41-54.

D. Baczała Niepełnosprawność intelektualna a kompetencje społeczne, Wydawnictwo Naukowe UMK, Toruń 2012. 
kompetencji społecznych rodzina prowadzi ich naturalny trening ${ }^{32}$. Postawa rodziny w stosunku do dziecka, a później dorosłego z niepełnosprawnością intelektualną determinuje proces kształtowania kompetencji społecznych i motywację do dalszego samodzielnego i świadomego partycypowania w życiu społecznym. Pozostaje pytanie, czy po opuszczeniu murów szkoły poziom aktywności obywatelskiej uczniów, szczególnie w kategoriach dotąd inicjowanych przez szkołę, zdoła się utrzymać.

Zgodnie z analizą statystyczną zebranych danych wykazano, że istnieje związek między doświadczaniem społeczno-kulturowych barier inkluzji a aktywnością obywatelską badanych uczniów szkoły przysposabiającej do pracy. Nie jest on tak silny, jak zakładano przy stawianiu hipotezy. Na uzyskany wynik mogła mieć wpływ specyfika badanej grupy. Badania podkreśliły rolę szkoły w treningu kompetencji społecznych. Najwyższe wyniki uzyskiwane przez uczniów w kategoriach aktywności obywatelskiej inicjowanych przez szkołę („społecznikostwo") świadczą o znaczeniu działań obywatelskich podejmowanych przez tę instytucję. Każą postulować, by szkolny trening kompetencji odbywał się systematycznie i obejmował szersze spektrum. Tymczasem dobre praktyki edukacji obywatelskiej zwykle pomijają środowisko osób z niepełnosprawnością intelektualną.

Uzyskane wyniki korespondują z wnioskami z badań kompetencji społecznych osób z niepełnosprawnością intelektualną̧33. Dorosłe osoby z niepełnosprawnością intelektualną:

1. oceniały wyżej swoje kompetencje społeczne, które zostały nabyte w konkretnej sytuacji społecznej;

2. mają niski poziom kompetencji społecznych, na co wpłynęło doświadczenie systematycznego deprecjonowania, obniżania samooceny i poczucia własnej wartości oraz odczucie społecznego odrzucenia.

Powyższe konkluzje przekładają się na wnioski z badań aktywności obywatelskiej:

1. w badaniu aktywności obywatelskiej badani uczniowie osiagali wyższe wyniki w kategoriach, w których posiadali doświadczenia (z inicjatywy szkoły), a niższe, gdy szkoła nie inicjowała danej kategorii aktywności; 
2. nadopiekuńczość wynikająca ze społecznego postrzegania osób z NI (jako bezradnych, bezsilnych i nieodpowiedzialnych) okazała się barierą doświadczaną i aktualną.

Warto zwrócić uwagę na ogólnie niskie odczuwanie barier społecznych przez badanych uczniów. Zgodnie z założeniami społecznego modelu niepełnosprawności ograniczenia w funkcjonowaniu osób z niepełnosprawnością mogą mieć różne wymiary. Zależą od kontekstu historycznego, porządku społecznego, panującego systemu politycznego i gospodarczego. Vicktor Finkelstein wykazywał, że zachodzące na przestrzeni dziejów zmiany gospodarcze wpływają na interpretowanie niepełnosprawności poprzez nasilanie lub słabnięcie trzech dominujących barier ${ }^{34}$. Bariery te zostały ujęte w kwestionariuszu subiektywnej oceny własnej sytuacji, a siła ich odczuwania przez badanych uczniów okazała się niska. Zgodnie z postulatami społecznego modelu niepełnosprawności nowa polityka społeczna wobec niepełnosprawności powinna "przezwyciężać upośledzające społeczeństwo"35. Odpowiedzi dotyczące subiektywnej oceny własnej sytuacji wybierane przez badanych mogą wskazywać, że tak się rzeczywiście dzieje. Przeobrażenia współczesnego świata pozwoliły znacząco przełamać wymieniane w latach 70. XX wieku bariery. Zgodnie z wynikami badań najsilniej odczuwaną barierą społecznej inkluzji jest poczucie własnej bezsilności. Osoby z NI stają się coraz bardziej obecne w życiu społecznym, wychodzą z domowej izolacji. Niemniej jednak ich społeczna partycypacja ciągle jest związana z kontrolą ze strony innych osób (rodziców, rodziny, specjalistów).

Ostatnie, trzecie pytanie kwestionariusza subiektywnej oceny własnej sytuacji dotyczyło doświadczania poniżających stereotypów kulturowych. Badanych uczniów proszono o ocenę postrzegania własnej wartości. Traktowanie siebie jako osoby bardziej wartościowej od innych było najczęściej wybieraną odpowiedzią. Poczucie własnej wartości jest wypadkową procesu wychowania, norm kulturowych, własnej atrakcyjności, poczucia sprawstwa i postrzegania otaczającego świata. Wynik ten może jednak tylko pozornie świadczyć o braku odczuwanych barier. Postępujący proces upodmiotowienia osób z niepełnosprawnością, wzrost zainteresowania ich sprawami i uznawanie ich potrzeb stają się cechami polskiej polityki społecznej. Równolegle dokonuje się wzrost społecznej kontroli życia osób z niepełnosprawnością intelektualną, który pogłębia poczucie zależności od innych 
i własnej bezradności ${ }^{36}$. Postrzeganie siebie jako bardziej wartościowego od innych może być, paradoksalnie, wynikiem oddziaływania poniżających stereotypów kulturowych, które dla osoby z niepełnosprawnością intelektualną przewidują rolę osoby słabej, niesamodzielnej, niezaradnej i nieodpowiedzialnej. W tym wypadku własne poczucie wartości wyrasta ponad wyjątkowo poniżający stereotyp. Osoby z NI czują się lepiej, niż „zakłada” to stereotyp społeczny.

Badani postrzegali siebie jako bardziej wartościowych również w wyniku oddziaływania postaw rodzicielskich i relacji rodzinnych. Polskie badania poświęcone tej problematyce podkreślają istotną pozycję dziecka z niepełnosprawnością intelektualną w rodzinie i dominującej rodzicielskiej nadopiekuńczości ${ }^{37}$.Zatem z jednej strony dziecko czuje się bardziej wartościowe i w takiej atmosferze wzrasta, a z drugiej strony postawa nadopiekuńczości (wyręczanie, brak wymagań, zwalnianie z wszystkich obowiązków czy dawanie pozornej swobody) powoduje wzrost poczucia bezsilności i bezradności. Dzieci tak wychowywane stają się osobami o wyższym poczuciu własnej wartości i jednocześnie bezradnymi, pozbawionymi poczucia sprawstwa.

Niepełnosprawność intelektualna powoduje ograniczenia w funkcjonowaniu osobistym i społecznym, których nie można w pełni skompensować. Społeczne postrzeganie tego typu niepełnosprawności pozostaje barierą najtrudniejszą do pokonania ${ }^{38}$. W kulturze dominującej, która prowadzi do internalizacji stereotypów, od zawsze panuje przekonanie, że dobrze jest być „młodym, zdrowym, mądrym, pięknym i bogatym, zaś źle starym, chorym, głupim, brzydkim i biednym" ${ }^{\text {"39 }}$. Kryteria te, choć głęboko zakorzenione, zostają dziś na skutek procesu pluralizacji powoli podawane w wątpliwość. Pytanie o definicję normalności staje się zagadnieniem filozoficznym, z którym nie radzi sobie na przykład współczesna psychiatria. Norma stała się pojęciem

Tamże, s. 53 .

B. Cytowska Ojcowie wobec opieki nad dziećmi z głęboką niepełnosprawnościq intelektualna i ich edukacji - studium etnograficzne, "Człowiek - Niepełnosprawność - Społeczeństwo" 2017 $\mathrm{nr}$ 2(36), s. 89-112. A. Malina, D. Suwalska-Barancewicz Stres i postawy rodzicielskie wśród matek i ojców dorosłych z niepełnosprawnościq intelektualnq, „Psychologia Rozwojowa” 2013 nr 18, s. 79-9o.

38 A. Gustavsson, E. Zakrzewska-Manterys Wprowadzenie: społeczny kontekst upośledzenia, w: Upośledzenie w społecznym zwierciadle, red. A. Gustavsson, E. Zakrzewska-Manterys, Wydawnictwo Akademickie Żak, Warszawa 1997, s. 25. 
kulturowym ${ }^{40}$. Osoby z niepełnosprawnością intelektualną pozostają wciąż grupą szczególnie narażoną na negatywną stereotypizację, a przez to na brak akceptacji dla swojego funkcjonowania społecznego. Pozytywne wartościowanie nie mieści się w brzydocie fizycznej i upośledzeniu umysłowym ${ }^{41}$.

W tym kontekście istotne zdaje się pytanie: czy współczesne społeczeństwa, skutecznie znosząc dotychczasowe bariery inkluzji, nie wprowadzają w ich miejsce innych, nowych? W jakim stopniu to obowiązujące kanony urody, kariery czy wzorce człowieka sukcesu takie bariery tworzą ${ }^{42}$ ? Czy weryfikacja postawionej hipotezy dla nowych społecznych barier inkluzji cechowałaby się wciąż tak słabą siłą korelacji? I czy poza bezpiecznymi murami szkoły specjalnej osoby z niepełnosprawnością intelektualną, które często charakteryzują się labilnością emocjonalną, introwersją, gwałtownością, problemami adaptacyjnymi, relacjami agresywnymi czy też zamykaniem się w sobie, będą potrafiły i mogły znaleźć miejsce do kontynuowania trenowanej w szkole aktywności obywatelskiej?

W 2015 roku powstał raport polskiego Rzecznika Praw Obywatelskich ${ }^{43}$ zawierający opis zidentyfikowanych barier prawnych, administracyjnych i organizacyjnych uniemożliwiających wdrażanie Konwencji praw osób niepełnosprawnych oraz charakteryzujący kierunki działań zmierzających do ich usunięcia. Z tego kompleksowego rozpoznania wynika, że osoby z niepełnosprawnością formalnie posiadające prawa obywatelskie nie mogą z nich w pełni korzystać: „Duża część postanowień KPON znajduje odzwierciedlenie w krajowym porządku prawnym, a osoby niepełnosprawne mają teoretyczną możliwość korzystania ze swych praw. Wadą systemową jest jednak niemożność ich faktycznej realizacji”" ${ }^{44}$. Martwe regulacje prawne wynikają z braku

40 J. Terelak Kontrowersje na temat użyteczności pojęcia normy w psychologii, "lus Matrimoniale" $2011 \mathrm{nr} 16$ (22), 299-315.

A. Gustavsson, E. Zakrzewska-Manterys Wprowadzenie, s. 25.

Por. G. Kubiński Wykluczenie społeczne osób niepełnosprawnych - perspektywa społeczno-kulturowa, w: Wykluczenie społeczne w Polsce. Wybrane zagadnienia, red. W. Klimczak, G. Kubiński, E. Sikora-Wiśniewska, Wydawnictwo Naukowe Exante, Wrocław 2017.

43 Biuro Rzecznika Praw Obywatelskich (BRPO) Realizacja przez Polskę zobowiq̨zań wynikających z Konwencji o prawach osób niepełnosprawnych, Sprawozdanie Rzecznika Praw Obywatelskich, Warszawa 2015.

44 Bariery prawne, administracyjne i organizacyjne wdrażania Konwencji o Prawach Osób Niepełnosprawnych oraz kierunki działań dotyczące przezwyciężania tych barier - raport syntetyczny, Polskie Forum Osób Niepełnosprawnych, Warszawa 2017. 
dostępu osób zainteresowanych do efektywnej pomocy prawnej i z faktu, że osoby reprezentujące państwo i właściwe w sprawie instytucje kierują się nadal uprzedzeniami wobec niepełnosprawności. Czas zatem na

traktowanie osób z niepełnosprawnością intelektualną jak wszystkich innych obywateli i stosowanie wobec nich (w praktyce) środków ochrony przewidzianych ze względu na stosunek prawny, którego są stroną, a nie ze względu na ich niepełnosprawność, tj. środków ochrony konsumentów, praw najemców, praw pracowniczych, praw pacjenta itp.; zastąpienie tradycyjnego ubezwłasnowolnienia systemem wspieranego podejmowania decyzji; oficjalne uznanie wszystkich dostępnych form komunikacji alternatywnej; zapewnienie dostępności narzędzi i nowoczesnych technik komunikacji. ${ }^{45}$

Czas skończyć z traktowaniem niedorozwoju umysłowego jako przeszkody w zawarciu małżeństwa zgodnie z Kodeksem rodzinnym i opiekuńczym z 1964 roku, który nadal obowiązuje $e^{46}$, i z równie przestrzałami zapisami Kodeksu postępowania cywilnego ${ }^{47}$. Te instytucje prawne wytwarzają schematy opresji, które są stosowane w imię wyższych wartości i zgodnie z literą prawa. Zostały stworzone w obawie przed innością i jej rozprzestrzenianiem. Obawie, która jest bezpodstawna.

Jeśli mam prowadzić dobre życie, musi to być życie prowadzone wspólnie z innymi, takie, które w ogóle nie jest życiem bez innych. Nie stracę w ten sposób swojego „ja”, którym jestem: to, kim jestem, zostanie przekształcone za sprawą moich kontaktów z innymi, ponieważ moja zależność od nich, a także moja zdolność udzielania im wsparcia, są niezbędne bym, mogła żyć, co więcej, żyć dobrze. ${ }^{48}$

45 Jeśli nie ubezwłasnowolnienie, to co? Prawne formy wspierania osób z niepełnosprawnościq intelektualnq, red. K. Kędziora, Polskie Towarzystwo Prawa Antydyskryminacyjnego, Warszawa 2012, s. 8-9.

48 J. Butler Zapiski o performatywnej teorii zgromadzeń, przeł. J. Bednarek, Wydawnictwo Krytyki Politycznej, Warszawa 2016, s. 190. 


\section{Abstract}

\section{Celina Kamecka-Antczak}

NICOLAUS COPERNICUS UNIVERSITY (TORUŃ)

\section{Ditta Baczała}

NICOLAUS COPERNICUS UNIVERSITY (TORUŃ)

Civic Activity Among Young People With Intellectual Disabilities: Socio-Cultural Barriers to Inclusion

The article presents the relationship between civic participation among people with an intellectual disability (ID) and Vic Finkelstein's barriers to social inclusion (which formed the basis for the questionnaire). A survey among adult students was also conducted with Richard Klamut's"Questionnaire on Civic Activity".The respondents tended to experience the barriers as small and their living conditions as good; they generally felt valuable. Only the subjective feeling of helplessness resulting from their own disability turned out to be significant. The stronger the experience of barriers, the less the respondents were politically active. A category with relatively high scores is engagement for the benefit of others, which is clearly attributable to special schools.

\section{Keywords}

person with an intellectual disability, active citizenship, social inclusion, special school 